\title{
Internationalization Strategies of French SME from the Agro-Alimentary Industry to China
}

\author{
Marion Blattner \\ Enterprise Management \\ Tongji University \\ Shanghai, China \\ marion.blattner@essca.eu
}

\begin{abstract}
This document is a preliminary article aiming to introduce this large and contemporary subject which will be the object of more advanced investigations in the following months. The sources of this article are both composed of readings and personal reflections and observations $I$ have been able to make while I was studying abroad in China during the past year, where I noticed the high success of foreign agroalimentary products within the country, especially in big cities. Most of the companies working in this field in France are SMEs (Small and Medium Enterprises), but only a few of them, despite the success of the agro-alimentary sector in France, are internationalizing their activities compared to other countries.
\end{abstract}

Keywords-internationalization strategy; SME; agroalimentary industry; China

\section{The Agribusiness: A High-Potential ECONOMIC SECTOR FOR FRANCE}

The agro-alimentary industry is one of the rare economic sectors in France to be in good health, but also to present a high potential both regarding the French territory and the export. According to the figures given by the French government of agriculture, the turnover recorded in this sector reaches 147 billion Euros in France. The internet website ania-export relates a trade surplus about 12 billion Euros in 2011, ranking it in the second position after the aeronautic sector in France. The same year, the country represented $6.5 \%$ of the word's market shares, making of it the $4^{\text {th }}$ world exporter before Germany. However, the French bureau of statistics "INSEE" reveals that the French IAA (Agro-Alimentary Industries) are less internationalized than the other industries within the country. The recent registration of the "French gastronomic meal" to the immaterial world heritage by the UNESCO only confirms the probable coming exports' growth in this sector, as it was for example the case in 2011 with a $14 \%$ rise in international sales. This growth is due to specific products in particular, such as wines and spirits. It is important not to believe that the whole sector is in great health; the INSEE essentially underlines the success of wines and spirits, dairy products and cereal products. The success of agribusiness is particularly noticeable in China, which represents a highpotential market.

\section{AND PROMISING REgARDING THE CHINESE MARKET}

The French Chamber of trade and industry in China (Chambre de Commerce et d'Industrie Française en Chine) estimated the Chinese agro-alimentary market at 140.4 billion dollars in 2011 and evaluated it as fast-growing. The economic stakes of this sector in China are high because of the important demand resulting (the Chinese population represents $20 \%$ of the world population indeed) and which could "grow by $25 \%$ in the horizon 2022 while China should grows its exports by $10 \%$ per year" according to the internet website ania-export. The alimentary demand explodes in China while the auto-sufficiency of the country in this domain is no longer topical, making it more and more dependent on the foreign countries. The growth potentials are thus huge for the French companies in the sector, especially since the emergence of a Chinese Middle-Class. This latter, linked with the rise of inhabitants in urban area as well as with the frequency of sanitary crisis in China (milk infected with Melanin affair, current avian flu, etc.), has conducted to a modification of the Chinese alimentary habits. They (and more specifically Chinese issued from the Middle-Class, which represents today more than 200 million consumers and could reach 700 million according to the internet website "altios-international") are now looking for quality products allowing them in the same time to benefit from a certain alimentary security. This is precisely the two main qualities of French products according to Chinese consumers... The Chinese agro-alimentary sector is not reaching the European standards yet (for example regarding sanitary norms): it is thus a huge growth opportunity for French companies working in this field to take advantage of. It is also the case concerning the luxury image given off by the French agroalimentary products sold in China, sometimes given as gifts thanks to their "brand" or even luxury image. The success brought by this latter is currently locally visible in China , especially in big cities such as Shanghai where an important and fast appearance of store names surfing on the wave of French "reputation" can be noticed, for example by giving themselves a "French touch" thanks to evocative names such as "Paris Baguette" or "Christine". These derivatives from French bakeries propose many products like breads and pastries adapted to Chinese tastes. According to the internet website "alimentation.gouv" from the French ministry of forest and agriculture, "the French agro-alimentary exports to China have been multiplied by seven these past ten years. 
However, only "wines and spirits" and "breads and pastries" can boast about having succeeded in convincingly seducing the Chinese market. Nevertheless, the other French agroalimentary products could break through in the same way.

\section{SubJeCt TO THE CONDITION OF GetTING THE SPECIFICITIES AND OPPORTUNITIES LINKED TO IT.}

China is well-known for its unique specificities, concerning as well regulations or languages as tastes and culture. These different aspects are thus important to manage for any company willing to develop in this country, especially, in our case, regarding alimentary habits. A longterm strategy is needed as well as a constant attention and listening about the subtleties of the Chinese market. The stake for the French products is, as explained Catherine Etchart, manager of Sopexa in Beijing, to "get integrated in alimentary habits far different from those of French people". There is a kind of enthusiasm for international brands, but the French Chamber of Trade and Industry in China also indicates that the Chinese brands remain the favorites of Chinese consumers. This organism also makes a reference to the lateness of French products in the agro-alimentary industry compared to other countries such as the United States or Chili, generally better adapted to Chinese marketing and culinary specificities. France thus has a challenge to take up to impose itself at the meantime on the Chinese market and faced with its international competitors. Many different helps are beginning to be brought by the French government to its SMEs as it wants to invest and reinforced this highpotential sector. French agro-alimentary companies, mostly SME/VSE with a high territorial settling down, are consequently still very little to be implemented in China except big national groups such as DANONE (The French ministry of foreign trade points out that nowadays, $80 \%$ of the French companies don't have any organized export cell and that a lot of them hesitate to get into it because of the financial risks). The French government has set up a "public package of export support gathering together different operators (UBIFRANCE, SOPEXA, ADEPTA) and aiming to hold up promotion actions of agro-alimentary sector within the world".

\section{AND LEADING TO NUMEROUS QUESTIONS REGARDING THESE INTERNATIONALIZATION STRATEGIES}

Therefore, considering the numerous stakes lead by this sector for French SMEs in the Chinese territory, it is possible to wonder:

\section{A. Which internationalization strategy is the most adapted to French SME from the agro-alimentary industry to succeed in China facing the great national and international companies?}

In 2005, BOURCIEU [1] underlines the necessity for SMEs willing to internationalize themselves to " coexist in the giants' shadow". In a direct competition context, it is better to avoid a direct confrontation with large companies. It is important to be able to mobilize resources and "to escape from the environmental constraint". There is thus a pressure linked with the environment for SMEs.
According to PEREZ (1996) [6], the products' characteristics, the localizations of the production and consumption areas can influence the internationalization process. According to the fact that the products of the agribusiness SMEs are banalized or differentiated, the competitive advantage of the internationalization strategy will be respectively focused on the costs 'management and the differentiation. According to their size, the companies will set up a "range" policy (large companies) or "niche" policy (small ones). It is also important to underline the importance of collective organizations for the SME's internationalization. The distinctive signs of quality are an important element in the differentiation strategies of agribusiness SMEs.

According to DEREZ and BLANC (2011) [2], the Chinese market is difficult to enter, but many SMEs meet there with success. It is important to place itself on qualitative niches in order to get differentiated from Chinese competitors, with whom the price-competition is impossible. The cultural differences have to incite the agribusiness SMEs to bring up the foreign consumers about their products. The obstacles linked with the structure of the Chinese economy have to incite SMEs to make use of support-solutions provided. It also seems strategic for these latter to create synergies between them and the large companies.

\section{B. To what extent is the innovation necessary to the internationalization of French SME from the agro- alimentary industry to China?}

Innovation highly participates in companies' competitiveness and profitability. In a study written by DEREZ and BLANC (July 2011) [2] about the French SMEs in China, the size of SMEs should favor their capacity of innovation thanks to the reactivity with whom researches can be developed there. Some SMEs thus use R\&D to "model their products' scale according to the Chinese market".

In their research made on the position given to innovation in the competitive strategies of international SMEs, ROY and TORRES (2001) [5] also underline the importance of innovation in the success in SME's export. A connection would exist between the innovative inclination of SMEs and the share of their turnover realized abroad. The companies succeeding in export are generally those applying a strategy linked with quality and innovation different from these of the local market, that is to say adapted to the target market. The protection of innovation strategies are thus also to take into account in the internationalization strategies of SMEs, which is more difficult for agribusiness companies, for example because of the impossibility of obtaining patents for recipes.

In its study on the international development strategies of SMEs faced with the dynamic of the institutional environment, BOURCIEU (2005) [1] underlines the importance of innovation in the highly competitive environments because it enables the survival of the company via the products differentiation, and especially specialization. 
However, BAILLY, BUCHAILLAT, OHIER, TOUSSAIN, MALPEL, MARCHAL and TEXIER (2011) [8] underline the small share of turnover of SMEs from the agroalimentary industry given to $R \& D$, et thus the importance for them to freely bring some appropriate supports to them in the innovation, export and research fields.

To what extent does the French State have to support and take part in the internationalization to China of French SME from the agro-alimentary industry?

According to TORRES (2002) [7], the highly territorialized functioning of SMEs doesn't hold their internationalization back; quite the opposite. He maintains that "the management of the "local" in the service of the "international" is a necessity for SMEs", as these latter are regulated by the concept of "proximity" which plays a fundamental part in their management. The author also introduces the notion of "glocalisation", a mixing between globalization and proximity inferring that the dimension and the strong local integration of SMEs is at the basis of their conquest of competitive advantages as well as their competitiveness on world markets. SMEs are based on their local resources to look for their external resources indeed. Nevertheless, this territorial settling down couldn't be a success without any "internationalizing environment" for the companies in the sector, that is to say without the cooperation of all of the players on the territory in which they are established.

FORT and COURDEC (2001) [3] introduce the notion of "local companies", in other terms companies maintaining strong links with a territory identified by cultural characteristics. According to them, the utilizing of the resources coming from the territorial settling down can only be exploited by this type of SME. The differentiation strategy is here still appropriate by playing with the production of alimentary products with a strong identity: the local products. The strong territorial settling down of agribusiness SMEs becomes here their trademark. The "local products" designation is only deserved after having followed very strict bill of specification on the product and production.

FORT and REMAUD [4] also underline the increasing place occupied by the "terroir" in the midst of the agroalimentary industry. Even if it is difficult to give it a precise definition, this geographic indication is still here associated with a "qualification and recognition of alimentary products' tool". The agro-alimentary companies adding the value to their products through the concept of soil would have an average export rate superior to the average. "If the size of the company remains an important criteria to develop the activity of the company regarding the export, the terroir enables to smaller companies to reach foreign markets". The search in a diversified alimentary consumption as well as the current fears potentially open the way to a lasting competitive advantage.

\section{CONCLUSION}

The understanding and definition of an internationalization strategy to China for French SME from the agro-alimentary sector is thus necessary to precisely answer these questions linked with the internationalization of French SME from the agro-alimentary industry to China. The analysis of the international development and internationalization of French SME from agro-alimentary industry as well as the performing perception and practice of the Chinese market among these types of companies will help fulfilling a double-objective: on the one hand, to find conclusions on the factors subtending the internationalization process of French SME from agro-alimentary industries and, on the other hand, the place of China in these strategies in order to help today's SME's managers from the agroalimentary industry in their internationalization process faced to the competition brought by multinational companies, and more specifically those willing to internationalize their activities in China.

\section{REFERENCES}

[1] BOURCIEU S., (2005), Les stratégies de développement international des PME face à la dynamique de l'environnement institutionnel (The international development strategies of SMEs faced with the institutional environment's dynamic), 14ème Conférence Internationale de Management Stratégique (AIMS), Angers, 5-7 June 2005

[2] DEREZ P., BLANC F., Les PME françaises en Chine (French SMEs in China), Ambassade de France en Chine (French ambassy in China), Service économique régional (Regional economic service), Shanghai, Jully 2011

[3] FORT F., COUDERC J-P (2001), Le terroir: un avantage concurrentiel à l'exportation? Le cas des entreprises agro-alimentaires du Languedoc-Roussillon (The terroir : a competitive advantage for export? The case of the agro-alimentary companies from LanguedocRoussilon), Économie rurale, vol.264, n²64-265, pp. 46-59

[4] FORT F., REMAUD H., Le processus de mondialisation dans la valorisation des produits agroalimentaires à travers le concept de terroir. Contrainte ou opportunité ? (globalisation process in the agroalimentary products' validation through the concept of «terroir ». Constraints or opportunities?), CIRAD

[5] LE ROY F., TORRES O. (2001), La place de l'innovation dans les stratégies concurrentielles des PME internationales (The place of innovation in international SMEs' competitive strategies), Innovations, vol $1, \mathrm{n}^{\circ} 13$, pp. 43-60

[6] PEREZ R. (1996), Sur l'internationalisation des industries et des stratégies des firmes alimentaires (About the internationalization of industries and alimentary companies' strategies), Économie rurale, Globalisation des économies agricoles et alimentaires, Situation et prospective, $\mathrm{n}^{\circ} 234-235$, pp. 29-33

[7] TORRES O. (2002), Face à la mondialisation, les PME doivent mettre du territoire et de la proximité dans leurs stratégies de glocalisation (Faced with globalisation, SMEs have to put territoru and proximity in their glocalisation strategies), Projet de communication pour la Xième Conférence de l'Association Internationale en Management Stratégique, Paris, 5-7 June 2002

[8] BAILLY.G, MALPEL.G-P, BUCHAILLAT.L, MARCHAL.P, TEXIER.P-H, TOUSSAIN.R (2005), Une stratégie publique pour les industries alimentaires (A public strategy for alimentary industries), Rapport pour l'inspection Générale des Finances et le conseil général de l'alimentation, de l'agriculture et des espaces ruraux, May 2012 